\title{
Perbedaan Rerata Feritin Serum antara Pria Obesitas Sentral dengan Non Obesitas Sentral
}

\author{
Ribka Wowor
}

Fakultas Kesehatan Masyarakat, Universitas Sam Ratulangi Manado

Email: ribkaladywowor@gmail.com

\begin{abstract}
Inflammation process that occurs in obese people plays a crucial role for cardiovascular events in the future. Animal studies found an association between macrophage and ferritin as a proinflammatory marker. This study was aimed to determine the difference in serum ferritin level between central obese and non central obese individuals. This was a cross sectional study using consecutive sampling mnethod. Subjects were residents of Medical Faculty, Sam Ratulangi University, consisted of 41 young males divided into two groups: 25 subjects with central obesity and 16 subjects without central obesity. Blood pressure, peripheral blood, serum ferritin, creatinine, and fasting blood sugar tests were performed on all subjects. The results showed that of 25 subjects with central obesity, there were 15 subjects with hyperferritinemia, meanwhile only 3 subjects with hyperferritinemia in non central obesity group. There was a significant difference of mean serum ferritin levels between central obesity and non central obesity groups $(303.03 \pm 171.53 \mathrm{mcg} / \mathrm{dL}$ vs $128.24 \pm 66.79 \mathrm{mcg} / \mathrm{dL} ; \mathrm{p}=0.000)$. In conclusion, serum ferritin level in male subjects with central obesity was higher than those without central obesity.
\end{abstract}

Keywords: serum ferritin, central obesity

\begin{abstract}
Abstrak: Inflamasi yang terjadi pada obesitas berperan penting terhadap kelainan metabolisme yang menjadi dasar terjadinya kelainan kardiovaskular. Pada hewan coba didapatkan adanya hubungan antara makrofag dengan feritin yang merupakan salah satu protein penanda inflamasi akut dan kronis. Penelitian ini bertujuan untuk mengetahui adanya perbedaan rerata ferritin serum pada individu dengan dan tanpa obesitas sentral. Desain penelitian ialah potong lintang dengan menggunakan konsekutif sampling. Subyek penelitian ialah mahasiswa PPDS Sp1 Fakultas Kedokteran Universitas Sam Ratulangi Manado terdiri dari 41 pria usia dewasa muda berusia kurang dari 40 tahun yang dibagi atas dua kelompok: 25 subyek dengan obesitas sentral dan 16 subyek non obesitas sentral sebagai kontrol. Pemeriksaan tekanan darah, darah perifer lengkap, dan kadar feritin serum dilakukan pada semua subyek. Uji statistik menggunakan uji beda rerata antara kadar feritin pada kedua kelompok. Hasil penelitian mendapatkan pada kelompok obesitas sentral, 15 dari 25 subyek mengalami peningkatan kadar feritin serum, sedangkan pada kelompok non obesitas sentral hanya 3 dari 16 subyek yang mengalami peningkatan kadar feritin serum. Rerata feritin serum pada kelompok obesitas sentral ialah 303,03 $\pm 171,53 \mathrm{mcg} / \mathrm{dL}$; sedangkan pada kelompok non obesitas sentral ialah $128,24 \pm 66,79 \mathrm{mcg} / \mathrm{dL}(\mathrm{p}=0,000)$. Simpulan penelitian ini ialah terdapat perbedaan rerata feritin serum antara subyek dengan obesitas sentral dibandingkan subyek non obesitas sentral pada pria dewasa muda.
\end{abstract}

Kata kunci: feritin serum, obesitas sentral, dewasa muda

\section{PENDAHULUAN}

Menurut World Health Organization (WHO), lebih dari 1,9 miliar orang dewasa pada tahun 2016 mengalami kelebihan berat badan, dan 650 juta di antaranya mengalami obesita. ${ }^{1}$ Hasil Riskesdas menyebutkan data obesitas di Indonesia yang terus mengalami peningkatan. Hampir 50\% provinsi di Indonesia memiliki prevalensi obesitas di atas prevalensi obesitas nasional. Sulawesi Utara 
sendiri merupakan provinsi dengan insiden obesitas yang tertinggi di Indonesia. ${ }^{2}$

Beberapa penelitian terdahulu membuktikan bahwa terjadi proses inflamasi pada individu dengan obesitas. Pada awal berlangsungnya penyakit, inflamasi yang terjadi pada obesitas berperan penting terhadap kelainan metabolisme yang menjadi dasar terjadinya kelainan kardiovaskular. ${ }^{3}$

Makrofag memegang peranan penting dalam proses inflamasi kronis yang terjadi pada obesitas sentral. Jaringan adiposa akan mengeluarkan sitokin-sitokin proinflamasi yang selanjutnya menyebabkan migrasi makrofag ke dalam jaringan adiposa. ${ }^{4}$ Pada penelitian dengan menggunakan hewan coba didapatkan adanya hubungan antara makrofag dengan feritin yang merupakan salah satu protein petanda inflamasi akut dan kronis. ${ }^{5,6}$ Berdasarkan hasil-hasil penelitian terdapat kemungkinan bahwa kadar feritin serum akan cenderung meningkat pada individu dengan obesitas sentral; hal ini yang melatarbelakangi penelitian ini.

\section{METODE PENELITIAN}

Penelitian ini merupakan penelitian potong lintang pada 41 pria usia dewasa muda berusia kurang dari 40 tahun, yang dibagi atas 2 kelompok: 25 subyek dengan obesitas sentral dan 15 subyek non obesitas sentral. Sampel penelitian ialah anggota populasi penelitian yang memenuhi kriteria inklusi dan eksklusi. Besar sampel pada penelitian ini ditentukan berdasarkan rumus Kirk yaitu minimal 30 sampel. Sampel diambil secara konsekutif sampling pada mahasiswa PPDS Sp1 di Fakultas Kedokteran Universitas Sam Ratulangi Manado. Pada subyek dlakukan pemeriksaan tekanan darah, darah perifer lengkap, dan kadar feritin serum. Kriteria eksklusi meliputi anemia, dan infeksi akut.

Pemeriksaan tekanan darah menggukan sphygmomanometer Riester. Lingkar pinggang diukur dengan posisi subjek berdiri pada kedua kaki berjarak $25-30 \mathrm{~cm}$ tanpa alas kaki. Posisi pemeriksa berada di samping subjek. Lingkar pinggang diukur melingkar secara horisontal dari titik tengah di antara titik puncak krista iliaka dengan tepi bawah kosta terakhir di linea medialis. Kriteria objektif obesitas sentral untuk lakilaki bila didapatkan lingkar pinggang (LP) $\geq 90 \mathrm{~cm}$. Uji beda rerata dilakukan antara kadar feritin pada kelompok obesitas sentral dibandingkan dengan kelompok non obesitas sentral.

\section{HASIL PENELITIAN}

Hasil penelitian ini memperoleh 41 subyek pria berusia 22-39 tahun; 25 subyek penelitian dengan obesitas sentral dan 16 subyek non obesitas sentral. Semua subyek penelitian memiliki fungsi ginjal normal (kreatinin kurang dari 1,2). Dari 25 subyek dengan obesitas sentral, 15 di antaranya mengalami peningkatan kadar feritin serum, sedangkan pada subyek non obesitas sentral hanya 3 dari 16 orang yang mengalami peningkatan kadar feritin serum.

Tabel 2 memperlihatkan hasil uji Mann Whitney tidak berpasangan antara rerata kadar feritin pada subyek obesitas sentral dengan subyek non obesitas sentral. Rerata feritin serum pada kelompok obesitas sentral ialah $303,03 \pm 171,53 \mathrm{mcg} / \mathrm{L}$, sedangkan rerata feritin serum pada non obesitas sentral ialah $128,24 \pm 66,79 \mathrm{mcg} / \mathrm{L}(\mathrm{p}=0,000)$.

Tabel 1. Karakteristik penelitian

\begin{tabular}{lccccc}
\hline \multicolumn{1}{c}{ Variabel } & N & Min & Maks & Rerata & SB \\
\hline Usia & 41 & 22 & 39 & 31,53 & 4,26 \\
Feritin (mcg/L) & 41 & 44,5 & 858 & 215,5 & 119,1 \\
Gula Darah Puasa (mg/dL) & 41 & 73 & 107 & 85,6 & 8,64 \\
Kreatinin (mg/dL) & 41 & 0,75 & 1,24 & 0,94 & 0,12 \\
\hline
\end{tabular}


Tabel 2. Perbedaan rerata feritin antara kelompok obesitas sentral dan non obesitas sentral

\begin{tabular}{clcccc}
\hline Variabel & \multicolumn{1}{c}{ Group } & n & Rerata & SB & p \\
\hline Feritin serum & Obesitas sentral & 25 & 303,03 & 171,53 & 0,000 \\
$(\mathrm{mcg} / \mathrm{dL})$ & Non obesitas sentral & 16 & 128,24 & 66,79 & \\
\hline
\end{tabular}

Keterangan: Uji Mann Whitney

\section{BAHASAN}

Besi berperan dalam proses metabolisme termasuk transpor oksigen, fosforilasi oksidatif, produksi energi, sintesis DNA, pertumbuhan sel, apoptosis, regulasi gen, dan juga proses inflamasi. ${ }^{7}$ Besi didistribusikan ke jaringan tubuh oleh transferin, suatu protein pembawa yang mengangkut besi dari enterosit intestinal atau makrofag ke dalam plasma, untuk selanjutnya disimpan pada molekul feritin. Setelah diserap, tidak ada mekanisme fisiologik untuk mengeluarkan kelebihan besi dari tubuh selain melalui perdarahan. ${ }^{8}$

Subyek penelitian ini semuanya ialah pria usia dewasa muda (kurang dari 40 tahun) sehingga kemungkinan terjadi bias pada kadar feritin akibat perdarahan karena haid bisa diminimalkan. Demikian pula kemungkinan terjadinya penurunan eritropoesis akibat penurunan fungsi ginjal seiring bertambahnya usia seseorang.

Pada penelitian ini didapatkan perbedaan rerata kadar feritin antara kelompok obesitas sentral dibandingkan kelompok non obesitas sentral, yaitu $303,03 \pm 71,53 \mathrm{mcg} / \mathrm{dL}$ vs $128,24 \pm 66,79 \mathrm{mcg} / \mathrm{dL}$. Hal ini kemungkinan karena pada obesitas sentral terdapat kelebihan jaringan adiposa yang ditandai dengan bertambahnya lingkar perut seseorang. Akibat kelebihan lemak intrasel maka liposom dalam hepatosit dapat meningkat ukurannya, membentuk vakuola besar yang disertai serangkaian keadaan patologik, termasuk penyakit perlemakan hati non alkoholik, steatohepatitis, dan sirosis. Jaringan adiposa juga memiliki fungsi endokrin utama yaitu menyekresi beberapa adipokin termasuk kemokin, sitokin, dan hormon. Dalam keadaan obesitas, adiposit merupakan bagian utama dari peradangan yang disebabkan oleh obesitas dengan peningkatan sekresi berbagai kemokin dan sitokin proinflamasi. ${ }^{9}$

Konsentrasi feritin bersamaan dengan hemosiderin menandakan jumlah persediaan besi di dalam tubuh. Sebagian besar besi terikat dengan protein pengikat besi, yang dikenal dengan feritin. Hemosiderin sendiri merupakan kompleks persediaan zat besi yang kurang siap untuk dilepaskan saat dibutuhkan oleh tubuh. Dalam keadaan seimbang, konsentrasi serum feritin berkorelasi baik dengan jumlah total besi dalam tubuh. ${ }^{10}$

Tempat utama sintesis feritin ialah hepatosit, akan tetapi setiap sel diketahui juga dapat memroduksi feritin. Dalam kondisi tertentu, feritin menjadi protein reaktan fase akut yang meningkat akibat proses inflamasi akut ataupun kronik. Beberapa kondisi inflamasi yang dapat meningkatkan kadar feritin ialah penyakit ginjal kronik, penyakit hati, keganasan, dan infeksi akut. Apabila terjadi kerusakan sel hati, maka feritin akan dilepaskan dalam jumlah besar ke peredarah darah. ${ }^{11,12}$

Hasil penelitian ini sejalan dengan penelitian dari Shattnawi et $\mathrm{al}^{13}$ yang mendapatkan bahwa terdapat hubungan antara kadar feritin dengan obesitas pada adolesen. Iwasaki et al ${ }^{14}$ juga meneliti tentang kadar feritin pada jaringan lemak dan didapatkan hubungan bermakna antara kadar ferritin serum dengan lemak viseral dan subkutan pada subyek obes.

Beberapa penelitian terdahulu membuktikan terjadinya proses inflamasi pada individu dengan obesitas. Pada awal berlangsungnya penyakit, inflamasi pada obesitas memegang peranan penting terhadap kelainan metabolisme yang menjadi dasar terjadinya kelainan kardiovaskular. ${ }^{3}$ Makrofag juga berperan penting dalam proses inflamasi kronis yang terjadi pada obesitas sentral. Jaringan adiposa akan mengeluar- 
kan sitokin-sitokin proinflamasi yang selanjutnya menyebabkan migrasi makrofag ke dalam jaringan adiposa. Pada penelitian menggunakan hewan coba didapatkan adanya hubungan antara makrofag dengan feritin yang merupakan salah satu protein penanda inflamasi akut dan kronis 5,6

Diet juga memegang peranan penting terhadap peningkatan kadar feritin dalam tubuh. Sumber utama besi heme dari hemoglobin dan mioglobin dari konsumsi daging merah, unggas, dan ikan; sedangkan besi non-heme diperoleh dari sereal, biji-bijian, buah-buahan dan sayuran. Besi heme lebih mudah diabsorbsi oleh tubuh (15-35\%) sedangkan besi non-heme lebih rendah (2$20 \%$ ) dan sangat dipengaruhi oleh komponen makanan lain yang dikonsumsi. Jumlah besi non-heme dalam makanan jauh lebih banyak dibandingkan besi heme yang tersedia. Besi non-heme berkontribusi banyak dalam memenuhi kebutuhan besi dalam tubuh dibandingkan besi heme. Adapun inhibitor penyerapan besi seperti asam fitat banyak terdapat dalam sayuran; polifenol yang terdapat dalam buah, sayur, sereal, kopi, teh, anggur; kalsium; dan peptide protein tercerna yang sebagian berasal dari sumber hewani olahan seperti susu, telur, dan albumin maupun nabati seperti kedelai. ${ }^{15,16}$

Dari hasil wawancara didapatkan bahwa sebagian besar subyek dengan obesitas sentral setiap harinya mengonsumsi daging merah seperti sapi atau kambing. Hal ini berbeda dengan kelompok non obesitas sentral yaitu hanya 5 orang subyek (33\%) yang mengonsumsi daging merah setiap hari. Hasil penelitian ini menunjukkan terdapat 3 subyek pada kelompok non obesitas sentral yang juga mengalami peningkatan kadar feritin melebihi nilai normal; hal ini mungkin disebabkan oleh faktor diet; ketiga subyek tersebut hampir setiap harinya mengonsumsi daging merah dan telur. Sebaliknya terdapat 2 subyek yang juga sering mengonsumsi daging merah namun tidak mengalami peningkatan feritin; hal ini mungkin disebabkan oleh faktor lainnya yang bisa menyebabkan penurunan kadar feritin serum.
Berdasarkan teori, olahraga atau aktivitas fisik intensitas sedang juga dapat memengaruhi kadar feritin serum. Pada penelitian oleh Beard dan Tobin ${ }^{17}$ didapatkan kadar feritin serum yang lebih rendah pada atlet marathon dibandingkan dengan individu non atlet. Kemungkinan terjadi proses hemolisis pada atlet atau subyek yang rutin melakukan aktivitas fisik. Keterbatasan pada penelitian ini ialah tidak dilakukan wawancara secara mendalam mengenai kebiasaan olahraga atau aktivitas fisik dari masing-masing subyek penelitian.

\section{Konflik Kepentingan}

Penulis menyatakan tidak terdapat konflik kepentingan dalam studi ini.

\section{SIMPULAN}

Terdapat perbedaan kadar feritin serum yang bermakna antara kelompok obesitas sentral dibandingkan dengan kelompok non obesitas sentral pada pria usia dewasa muda. Diperlukan usaha untuk mengurangi kadar feritin serum pada individu dengan obesitas sentral agar dapat mencegah terjadinya penyakit kardiovaskular di kemudian hari.

\section{DAFTAR PUSTAKA}

1. WHO. Overweight and obesity. WHO. 2018. [cited 2020 Jun 29]. Available from: http://www.who.int/gho/ncd/risk_factor s/overweight/en/.

2. Kementerian Kesehatan RI Badan Penelitian dan Pengembangan. Hasil Utama Riset Kesehatan Dasar. Kementerian Kesehatan Republik Indonesia. 2018; p.1100

3. Skinner AC, Perrin EM, Moss LA, Skelton JA. Cardiometabolic risks and severity of obesity in children and young adults. NEJM. 2015;373(14):1307-17.

4. Cohen LA, Guiterez L, Weiss A. Serum ferritin is derived primarily from macrophages through a nonclassical secretory pathway. Blood. 2010;116(9):1574.

5. Wesselius LJ, Nelson ME, Skikne BS. Increased release of ferritin and iron by iron-loaded alveolar macrophages in cigarette smokers. Am J Respir Crit Care Med. 1994;150(3):690

6. Ferring-Appel D, Hentze MW, Galy B. Cellautonomous and systemic context- 
dependent functios of iron regulatory protein 2 in mammalian iron metabolism. Blood. 2009;113(3):679

7. Frazer DM, Anderson GJ. Intestinal iron absorbtion and regulation. Am J Physiol Gastrointest Liver Physiol. 2005;289; 631-5.

8. Abbaspur N, Hurrell R, Kelishadi R. Review on iron and its importance for human health. J Res Med Sci 2014;19(2):16474.

9. Tchkonia T, Thompson T, Zhu Y, Karagiannides I, Pothoulakis $C$, Jensen MD, et al. Mechanisms and metabolic implications of regional differences among fat depots. Cell Metab. 2013;17(5):644-56.

10. Nadadur SS, Srirama K, Mudipalli A. Iron transport and homeostasis mechanisms: Their role in health and disease. Indian J Med Res. 2008;128(4):533-44.

11. Wang W. Serum ferritin: Past, present, and future. Biochimica et Biophysica Acta. 2010;1800(8):760-9.
12. Adams P. Management of elevated serum ferritin levels. Gastroenterol Hepatol (NY). 2008;4(5):333-4.

13. Shattnawi KK, Alomari MA, Al-Sheyab N, Salameh AB. The relationship between plasma ferritin levels and body mass index among adolescents. [cited 2020 Jun 29]. Available from: www.nature. com/ scientificreports. 2018; p. 1-6.

14. Iwasaki T, Nakajima A, Yoneda M, Yamada Y, Mukasa K, Fujita K, et al. Serum ferritin is associated with visceral fat area and subcutaneous fat area. Diabetes Care. 2005; 28(10):2486-91

15. Hurrell R, Egli I. Iron bioavailability and dietary reference values. Am J Clin. 2010; 91(5):1461-7.

16. Reddy M. Hurrel R, Cook J. Consumption in a varied diet marginally influences nonheme iron absorption in normal individuals. J Nutr. 2006;136(3):576-81.

17. Beard J, Tobin B. Iron staus and exercise. Am J Clin Nutr. 2000;72(suppl):594S-7S 